\title{
FENER VE TÜRK ORTODOKS PATRİKHANESİ
}

\author{
Hikmet Yavuz ERCAN
}

Roma İmparatorluğunun ikiye ayrılması daha sonraki yıllarda hıristiyan âleminin de ikiye ayrılmasına sebep oldu. Bilhassa Batı Romanın yıkılmasından sonra eski Roma rolünü oynayan Bizans, o günkü siyaseti icabı Romadaki papayı değil, İstanbuldaki patriki en büyük hıristiyan ruhanî lider olarak tanımaya başladı. VI. y.y. da başlayan bu ayrılık gittikçe artarak XI. y.y. da kesin şeklini aldı. 1053 yılında Ortodoks mezhebini kabul etmiş olan doğu hırıstiyanları, İstanbulda Ortodoks Patrikhanesini resmen kurdular ve Roma Katolik Kilisesinden kesin olarak ayrıldılar. Bir ara Latinlerin İstanbulu ele geçirmeleri (1204) ile sarsıntıya uğradıysa da Bizans İmparatorluğunun yıkılışına kadar fasılasız devam etti. Ancak Kilise, Doğu Roma İmparatorluğu gibi sonraları basit bir değişim geçirerek Grek Kilisesi şekline dönüştü. Yahut Doğu Roma'dan armağan kalan ismiyle Rum Patrikhanesi oldu.

Selçukluların Anadolu'yu fethi ile başlayan Türk tehlikesi, Osmanlıların Avrupada ilerlemeleriyle büyük bir korku halini aldı. Hatta bu korkunun tesiriyle Katolik ve Ortodoks Kiliseleri birleşme zemini aramaya başladılar. İki kilise arasındaki ayrılık o kadar fazla, buna rağmen Osmanl idaresi o kadar adaletli idi ki böyle bir günde söylenen "İstanbulda kardinal külahı görmektense Osmanlı sarı̆ı görmeyi tercih ederim" sözü dikkate şayandır. Gerçekten Türkler İstanbul'u fethettikten sonra, huristiyan halka karşı olan tutum ve hareketleriyle bu sözün ifade ettiği anlams kat kat aştılar. Bizzat Fatih'in fermanlarıyla, çökmek ve dağllmak veya Katolik Kilisesinin kucağına düşmek üzere bulunan Ortodoks Patrikhanesi kurtarıldı. Dağınık ve perişan bir halde olan Ermeni Kilisesi İstanbulda yeniden kuruldu.

Türk hakimiyetine geçtikten sonra ilk defa Georges Scolarius, "Gennadios" adıyla patrik oldu. Ne yazıkki bu patrikler ve Ortodoks 
din adamları malûm menşe ve yetişme tarzları sebebiyle her zaman Türklük aleyhinde çalıştılar ve her fırsatta bu hislerini açı̆ga vurdular. Osmanlı tarihinde bu yüzden cezalandırılan patrikler vardır. Bunlardan ilki III. Partenios olup, 1657 yılında Köprülü Mehmet Paşa tarafindan astırıldı. ${ }^{1}$ Asılma sebebi şudur: "İstanbulda Rum Patriki olan müfsid, Eflâk Voyvodası Konstantin nam pelid'e ilka-i fesadı mutazammin ekâzible memlû gönderdiği varaka-i batıla tutulub hiyaneti zahir olıcak kendüye gösterilüb sual olundukda cevaben, beher sene sadaka tahsili için bu makule kâğıt göndermekteyiz deyu ikrar etmegin Parmakkapı'da salb olundu. Mel'unun kâğıdında olan mazmun bu ki; Müddet-i devr-i İslâm temam olmağa az kalmıştır. Velvele-i din-i İsevî tekrar âlemgir olacaktır. Ana göre tedarikde olasız. Ankarib cümle vilâyetler Mesihîler eline girüb eshâb-ı salib ve nâkus temam memâlike

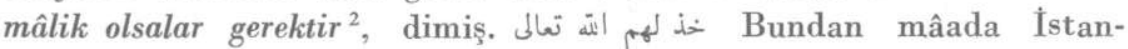
bulda vaki olan fitnelerde ve ihraklarda metin ve tuvana kefereler dolama ve fes giyüb, yeniçeri kıyafetine girüb yağma ve talan ve ümmet-i Muhammede uzrar ve ihanete cür'et ettikleri ol vakitde gayet şüyu' bulmuşdu. Patrik ahz olundukda mènzili basılub kırk elli kat dolama ve fes ve yeniçeri üsküfü çıkub bu kelâmı tasdik etmiş. Asłı tefassuh olundukda Fener kapusını bekleyen çorbacı neferatınındır deyu def-i töhmet etmişler". ${ }^{3}$

Asılan patriklerden diğeri V. Gregorius'dur. 1821 Yunan İsyamı ile yakından ilgili olan patrik "Mah-ı Recebin ondokuzuncu paskalya güni olan yevm pazar Sadr-1 a'zam ${ }^{4}$ ba irade-i celâdet ifade-i hazret-i şehriyarî Rum Patrikini Bâb-ı Âli'ye ihzar idüb" 5 sorgusu yapıldıktan sonra suçu sabit görülüp "kethüdası ile Petro kapusında karşı karşıya salb ile icra-i ceza ifa-i hükm-i kaza kılındı. Ve akabince Kayseriyye ve İzmid ve Tarabya metropolidleri kaldırılub Balıkpazarı kapusına ve Kaşıkçılar Hanı önü ve Okçularbaşı Parmakkapularına salb olundudular. Ve Rum taifesi müteayyinan ve bazirgânı makulesinden fesadda yed ve medhali haber alınmış ve ana dair bazı kâğıtlan tutulmuş beş

\footnotetext{
1 Uzunçarşılı, İ. Hakka; Osmanlı Tarihi, c. $3 / 1$, s. 382.

2 Sadaka toplamak için kullanılan dil pek ilginȩ olduğundan italik harflerle yazıld.

3 Naima; Tarih, e. 6, s. 252.

40 zaman sadrazam Benderli Ali Paşa idi.

5 Mehmed Ataullah; Tarih-i Şanîzade, c. 4, s. 29.
} 
nefer müfsidan dahi sair mecmu'-1 nas mahallerde katl ve ibret-i akran oldular". 6

V. Gregoris'un cesedi üç gün darağacında bekletildi. Boynunda asılı olan yaftada, bir patrikin yapması gereken işler ve Gregorius'un işlediği suçlar yazılıydı. Denize atılan cesedi Rumlar tarafından bulunarak önce Odesa'ya götürüldü. 1871 yılında Yunan Hükümeti Meclis'in kararıyla Atina'ya getirtti. Rumların Türkler aleyhine çalışmaları bundan sonra daha çok kesifleşti. Bu olay rumların elinde bayrak oldu. $\mathrm{O}$ günden itibaren Fener Patrikhanesinin Petro Kapısı (Ortakapı) kapatıldı. Bugün de halâ kapalı durmaktadır. Yalnız dikkate şayandır ki Osmanlı Tarihinde, XX. y.y.a gelinceye kadar Rum isyanları ya Yunanistan'da veya İstanbul'da olmuştur. Anadoludaki Ortodoks halk -din adamlan müstesna- bu hareketlere pek karışmamışlardır. Bunun sebebi Anadolu Ortodokslarının dil, kültür ve gelenek bak̉ımından Türklüğü benimsemeleriyle ilgili olmalıdır. Gerçekten XIX. y.y. sonlarına kadar Antalya Rumlarının bir kelime rumca bilmedikleri, orada ilk defa rumca öğreten Nikolaidis adlı bir Yunan tarafından itiraf edilmiştir. ${ }^{7}$ Antalya gibi deniz kenarında bulunan bir şehirde durum böyle olursa, Anadolu kıtasının içinde oturan Ortodoksların, Yunan ve Rum'luk meseleleriyle ilgilenmemiş olmaları pek tabiidir. Ne yazıkki Antalyada yapılmaya başlanan "Yunanlılı" propagandası tek kalmadı, büyük bir hıla bütün Anadolu'ya yayıldı. Anadoludaki Ortodoks halkın içtimai durumuna ve Anadoludaki Yunan propagandasına örnek teşkil etmesi bakımından Karamanlı bir Ortodoksun (Yorgi) Kurtuluş savaşı sırasında oğluna hitaben yazmış olduğu vasiyetnamesinden aldığımız bazı parçaları aşağıya naklediyoruz. “...Ben Karamanlı öyle bir Rum idim ki; Dünyada Müslümanlar kadar kimseyi sevmezdim...

...O esnada köye bir Yunanlı geldi. Gizli gizli Rum ahaliye ömrümüzde işitmediğimiz, bilmediğimiz şeyler söylüyordu. Bunlar bizim eski ecdadımızın isimleri imiş.

6 Mehmed Ataullah; ayn eser, c. 4, s. 30.

7 Galanti, Avram; Ankara Tarihi, s. 115. "Antalya Rum ahalisi bundan seksen sene evvel yunanca bilmezdi. Bunu, bundan elli sene evvel Rodos'da bana yunanca ders veren Nicolaidis söyledi. Nicolaidis Antalya'da en evvel yunanca okutan muallim oldu. Bu muallim bana:

- Antalya'ya geldiğim vakit, Rumlar yunancadan bir harf bilmezlerdi, dedi". 
Biz evvelden büyük bir imparatorluk imişiz. Sonra vahşi Türkler memleketimizi istila etmiş, kadınları ve çocukları, ihtiyarları ateşlere atmışlar, gençleri baştan başa kılıçtan geçirmişler imiş...Daha bilmem neler. İlk toplantımızda bizim asırlardanberi sevgili vatandaşımız olan Türkler aleyhinde, vahşi, kaba, canavar iftiralarını işitmek bize ağır geldi...Bir gün geldi ki, o telkinatın tesiri beni fena halde zehirlemişti. Ondan sonra Türklere karşı ebedî bir kin ve düşmanlık hisleri duymaya başladım...

...Türk unsurunun imhası için Yunanistana koştuk, çeteler teşkil ettik. Köyleri yaktık, muhacirleri arabaların içerisinde birer birer boğazladık, kadınların, kızların ırzına geçtik. Esirlerin gözlerini oyduk, burunlarını, kulaklarını kestik. Öyle facialar meydana getirdik ki oğlum, şimdi onların korkusu ile titriyorum, boğuluyorum!..

...Ah kör olsun beni baștan çıkaran o Yunanlı domuz!..

...Ben öldükten sonra bu vasiyetnameyi aynı ile gazetelere dercet. Yunanlıların adi iğvalarına kapılanların ne kadar müthiş bir vicdan azabı içinde kıvranarak ilahî cezaya dûçar olduklarını herkes benden ibret alarak öğrensin". 8

Yunan propagandasının 'bu süratli yayılışında bir çok etkenler vardur. Bu işde en büyük destek Yunan Hükümeti idi. Ayrica muntazam bir teşkilata sahip olan kilise, bütün gücüyle karşılıksız olarak çalıştı. Osmanlı İmparatorluğu ise bu olaylara karşı koymak yeteneklerine sahip değildi. En önemlisi Anadoludaki iki halk arasında din farkı vardı ve kiliseye mensup din adamları Rum'luk ile Ortodoks'luğu kaynaştırmayı çok iyi bildiler. Zaten İstanbulun fethinden sonra Bizans Kilisesi, Fatih'in vermiş olduğu dinî otonomiyi, İmparatorluğun zayıflamasına paralel olarak suistimal ederek mahiyet değiştirmiş ve Grek Kilisesi haline gelmişti.

Osmanlı İmparatorluğu Balkan Savaşında yüz kızartıcı bir yenilgiye uğrayınca artık, bilhassa İstanbuldaki gayr-i müslimler açıktan açığa devlet ve Türklük aleyhine çalışmaya başladılar. Bab-ı Âli daha Balkan Savaşının dumanları tüterken I. Dünya Savaşına katıldı ve bu onun sonu oldu. Galip devletler Türk topraklarım paylaşırken Yunanistan Anadolu'yu işgale başladı. Denilebilir ki Türkiyedeki

8 Mısıroğlu, Kadir; Yunan Mezalimi, s. 249. 
Rumlar Yunanistan'dan daha büyük zararlar açtı. Yunan Ordusu Kütahya'ya kadar gelebildi ise bu sayede geldi.

Rum okullarında Türkçe okumak yasak edildi. Yunan donanmasının İstanbula girişini kutlamak için okullar kapatıldı. Rum ve Ermeni patrikhanesiyle, Yahudi Hahamhanesi Türk ordusunda bulunan gayr-i müslim askerlerin serbest bırakılması için çalışmalara başladılar. Rum Patrikhanesine Yunan bayrağı ve Bizans kartalı asıldı. Ayasofya'yı işgal edip tekrar kiliseye çevirmek için hazırlık yapıldı. Fakat önceden haber alındığından başarılamadı. Trakyadaki papazlara Yunan askerleri geldikleri zaman karargâhlarına gidip takdis etmeleri emredildi. Londra'da çıkan Times gazetesine, Rumlar lehine yaptığı neşriyattan dolayı teşekkür telgrafı çekildi. Edirne işgal edildikten sonra, Edirne metropolidi Polikaryos Atina'ya giderek Venizelos'a teşekkür etti. Venizelos'un Paris'de Yunanlılı adına yapılan teşebbüslerini desteklemek için, patrikhanenin teşvikiyle otuz kişilik bir heyet Paris ve Londra'yı ziyaret ederek, Fransa ve İngiltere devletleri başvekillerine birer muhtıra verdiler. Harp yıllarında itilaf devletlerine mensup bazı denizaltılar Çanakkale boğazından Marmara'ya girmişlerdi. Bu gemilerin ihtiyaçlan Rumlar tarafindan temin edildi Izmir'in işgalinden sonra Patrikhanenin teşvikiyle bazı Rum'lar İzmir'e giderek Yunan ordusuna gönüllü yazıldı. İngiliz Parlamentosunda Ortodoks'lar lehine ateşli bir nutuk veren Kanterbori bașpiskoposuna telgraf çekilerek Patrikhane adına teşekkür edildi. Anadolu ve Trakya'da sayısız yağma, tecavüz ve cinayet işlendi. Bütün bunlar I. Dünya Savaşı sonunda ve Kurtuluş Savaşı yıllarında, Fener Patrikhanesi marifetiyle meydana getirilen olayların bir kısmıdır ${ }^{9}$. İstanbuldaki Rum matbuatı da Patrikhanenin teşvikiyle yayınlar yaptı. Bunlardan Rum Patrikhanesinin resmî gazetesi olan Eklisiyastiki Alitia'da şöyle yazılar yazılacak kadar ileri gidildi ${ }^{10}$; “...Bir milletin, müsavat vaitleriyle iğfal edildiği zamanlar geçmiştir...Bu devlet yıkulyor. Bu köhne ve hâyide vaitlerle devlet toplanamayacaktır. Coğrafî istatistikler serdi de Türk unsurunun ekseriyeti haiz olduğuna ve binaenaleyh Rum milletinin de böyle batıl tarz-ı tesviyelerle idare-i maslahat edilmesi lazım geldiğine kimseyi ikna edemez. Haritaları tertib edenler unutmamalıdır ki, Rum unsuru bir çok yerlerde

9 Aynî, Prof. M. Ali; Milliyetçilik, s. 310 v. d.

10 Akşam; No: 46, 4 Teşrinisani 1918. 
ekalliyette ise baba mirası üzerindeki tarihî ve içtimaî hukukunu kaybedemez..." Burada bilhassa üzerinde durulması gereken deyim "baba mirası"dır. Bu deyimle, Yunanlılarla Bizans arasında tarihen izahı güç bir akrabalık kastedilmiş olmalı, Aynca yazarın ifadesine göre, "baba mirası" dediği Anadolu'da Greklerden önce hiçbir milletin oturmadığı anlaşılıyor. Oysa tarihî gerçekler hiç de böyle değildir. Kaldı ki bir yerin mülkiyeti baba mirası, dede mirasıyla ölçülmez, o yerin o anda sahip olduğu çehre ile ölçülür. Anadolu bu gün değil, Selçukluların geldiği gündenberi Türk olmuştur ve Türk çehresine sahiptir.

Patrikhanenin bu ve buna benzer çalışmalan özellikle İstanbul ve Trabzon çevresinde başarılı oldu. Anadolu'nun diğer bölgeleri her şeye rağmen bu gibi tahriklere pek kapılmadılar. Bunun en önemli sebepleri Anadolu Ortodokslarının, Fener ve Yunan Hükümeti adamlarının tahriklerinden nisbeten uzak kalması ve başlarında Papa Eftim'in bulunmasidir.

$\mathrm{Bu}$ güne kadar Fener Patrikhanesi ve faaliyetleri hakkında ne kadar çok yazı yazılmışsa, Papa Eftim ve Türk Ortodoks Patrikhanesi hakkında da aksine pek az yayın yapılmıștır. Oysaki Kurtuluş Savaşında Papa Eftim'in çalışmaları başh başına bir konu olabilecek niteliktedir. Atatürk'ün "Millî Mücadelede bize bir ordu kadar yardım etti" sözü Papa Eftim'in çalışmaların bir cümle ile ifade etmektedir ${ }^{11}$. Ne varki aydınlarımızın bir kısmı ve halkımızın büyük çoğunluğu Papa Eftim'den ve hele Türk Ortodoks Patrikhanesinden habersizdirler. Bu sebeple asıl gayemiz, zaten malûm olan Fener Patrikhanesinin tarihçesini vermek değil ${ }^{12}$, Papa Eftim'i ve Türk Ortodoks Patrikhanesinin kuruluşu ile faaliyetlerini tantmaktır.

Papa Eftim 1300 (1884-1885) yılında Ankara vilayetinin, Yozgat sancağına bağlı Akdağmadeni kasabasında, İstanbulluoğlu ma-

11 Karakurt, Ali; Fener Patrikhanesinin İçüzü, s. 31.

$12 \mathrm{Bu}$ konuda geniş bilgi için şu eserlere müracaat edilebilir:

Anadolu Hediyesi; aylik dergi İstanbul, 1921.

Aynî, Prof. M. Ali; Milliyetçilik, İstanbul, 1943.

Ergene, Teoman; İstiklal Harbinde Türk Ortodoksları, İstanbul, 1951 (Bu kitap ayrica 11 Arahk 1950 tarihinde Zaman-Akşam gazetesinde tefrika edilmiştir),

Kitsikis, Dimitri; Yunan Propagandası, İstanbul.

Karakurt, Ali; Fener Patrikhanesinin İçüzü, İstanbul, 1955.

Misuroğlu, Kadir; Yunan Mezalimi, İstanbul, 1968.

Sâlışı, Selahattin; Türk-Yunan Ilişkileri Tarihi ve Etniki Eterya, İstanbul, 1968. 
hallesinde dünyaya geldi. Asıl adı Pavli Karahisarlığlu'dur. Kendisine büyükbabasının ismi verilmiştir. Babası tüccardı ve kendileri Karahisarlıoğlu lakabıyla tanınırdı. Bu, soyunun Karahisar'dan geldiğine dair bir delil olabilir.

Küçüklüğünde bir müddet kilise okuluna gitti. Okumayı yazmayı orada öğrendi. Daha sonra rüşdiyeye devam etmeye başladı. Rüşdiyedeki hocası Şevki Efendinin pek çok sevgisini kazandı ${ }^{13}$. 1908 de Ankara'ya gitti ve babasının mesleğine intisap ederek manifatura tüccarlığına başladı. 1911 de evlendi. 1912 de diyagos ${ }^{14}$ ve 1915 de papaz olarak memleketine döndü. Kendisini Kayseri metropolidi ${ }^{15}$ Nikolaos takdis etti. 1918 de ise Keskin metropolit vekili olarak Keskin'e gitti. Millî Mücadeleye atılması aşağı yukarı bu yıllara rastlar. Papa Eftim'in kendi ifadesi olan aşağıdaki sözler, onun manevî dünyasını gayet güzel yansıtmaktadır ${ }^{16}$. “...Beni yakından tanıyanlar pek iyi bilirlerki gösteriş ve şahsî propagandadan hoşlanmam, Bir övünme ve ululanma sayılamayacağından emin òlarak biraz kendimden, şahsımla ilgili gerçeklerden konu açmama müsaade edilmesini rica ederim:

Ben, 10 yaşımdanberi mukaddes kitablarla meşgul olmaya başladım. Mukaddes kitapların leh ve aleyhinde yazılmış neye rasladımsa, hepsini okumaya çalıştım. Bundan başka kırk yıldanberi, her gün en az üç sabah, iki akşam gazetesi ve bir çok mecmualar okumayı da itiyad edinmişimdir. Diyebilirim ki hayatım geceli gündüzlü, okumak ve yazmakla geçmektedir. Günde altı saat olsun uyumaya kendimi

13 Ergene, Teoman, Istiklal Harbinde Türk Ortodoksları, s. 5: Karakurt, Ali; Fener Patrikhanesinin İ̧̧ÿ̈ü, s. 31. Bu ikinci eserde bizzat Papa Eftim'in şifahî beyanatı vardır. "Ben Türk Ortoduksuyum. Yozgat sancağının Akdağmadeni kasabasında doğdum. Rüşdiyede Hoca Şevki efendinin rahle-i tedrisinde yetiştim ve Millı Mücadeleye herkesten evvel iştirak ettim".

14 Ruhban sımıfı üç kısımdır,

a) Diyagos.

b) Papaz.

c) Episkopos.

Diyagos, bunların birincisidir. Bu üç sınıf yalnız takdis ile olur. Bunun dışında olanlar ise -mesela; başepiskoposluk gibi- rütbe ile verilir.

15 Metropolit bir üst rütbeye terfi etmiş episkopos demektir. Başepiskoposlukla metropolitlik ayn makamdır. Metropolit bir bölge veya vilayetin dinî amiridir. Emri altında birkaç episkopos bulunabilir.

16 "Papa Eftim’in Kıbrıs Hakkındaki Görüşleri". Bu broşür 1958 yılında Papa Eftim tarafindan yayınlanmıştır. 
zorlarım. Ruhumu öyle terbiye etmiştim ki uykuda bile sanki bana bir çok yeni şeyler öğreten bilgilerle meşgul olurum, Kendimi bu derece ilm ü irfana bağladığım halde, yine de bir hiç olduğum kanaatini taşımaktan asla çekinmemişimdir. Böyle olmakla beraber, ilahî bilgiler ve tecrübeler içinde itikad ve imanımla şu fani ömürden gücüm yettiği kadar zevk duymaktayım. Bunun bana bir ilahî lütufkârlık olduğuna inanıyorum. Çünkü dünyaya geliş sebebimi ve insanlığa karşı ödevlerimi kavramaktan ileri geldiğine inanıyorum. Bu inanış, bedenimi ve ruhumu saadete kavuşturuyor. Ulu Tanrım'a şükürler olsun ki çok mesut ve bahtiyarım.

Ben Ortodoks hırıstiyan olarak doğdum. Ana dilim Türkçedir. Rumca, ermenice, fransızca, arapca, farsca da öğrenmeye çalş̧ıิı. Dinimin ve kilisemin ana dili olan rumca ile mukaddes kitabı ezberlediğimden, bu dili çok iyi anlarım. Diğer yabancı dilleri ise unutmuş gibiyim.

Millî ve dinî duygularımm sağlamlığı, millîyetimin Türk, din ve mezhebimin ise, Ortodoks olduğunda beni hi̧ bir zaman şüphe ve tereddüde düşürmemiştir..."

Papa Eftim'in millîyet anlayışı şöyledir: “...Dinini değiştiren bir ferdin mutlaka milliyetini de, ırkını da değiştirmesi gerekmez. Esasen buna imkân da yoktur. Din değiştirmek bir arzu ve irade meselesidir. Irk ve millîyet ise, insanın arzu ve iradesine değil, dile, kültüre, tarihî münasebetlere bağhdır. Din, Allah'a ait ve vicdana merbut bir hadisedir. Millîyet ise tamamiyle içtimâ̂, tarihsel bir vakıadır. Aynı millîyet içinde çeşitli din ve mezhepler olduğu gibi, ayn dine mensup olanlar da ayrı urk ve milliyet duyguları taşıyabilirler ${ }^{17}$..."

Millîyet konusunda, bazı Türk gazetecileri Papa Eftim'e "Türk dostu Eftim" dedikleri için, O buna pek çok üzülmüş ve "Ben Türk dostu Eftim değil, Türk oğlu Türk Eftim'im" diye cevap vermiştir. “...Ben her zaman, her yerde Türk olduğumu beyan ettim. Bir yabancı Türk dostu olabilir. Fakat benim gibi halis bir Türk vatandaşının bir yabancı Türk dostu gibi gösterilmesi, onun millîyetinden şüphe edildiğine yol açar ki bundan incinmemek, teessür duymamak imkânsızdır. Kendi milletinin dostu olmak bir Türk için tabî̂ zarurî, mantıkîdir. Bu böyle olunca bir Türk'e, Türk dostu demekle tezata, mantıksızlığa düşülmüş olmazmı?

\footnotetext{
17 Aym broşür.
} 
Bana Türk demeyip, Türk dostu diyenleri hiçbir suretle af ede$\operatorname{mem}^{18} \ldots "$

Tarihî gerçekler hiç bir devirde tek başına faydalı olmamıştır. Bu faydayı temin edebilmek için tarih biliminin içinden, tarih şuurunu elde etmek lazımdır. İşte Papa Eftim bunu başarabilmiştir. Anadolundaki bütün Rumlara Yunan ruhu aşılanmış ve Grek damgası vurulmuştur. Oysa tarihî gerçekler böyle değildir. Grekler Anadolu' ya gelmeden önce bir çok başka milletler vardı. Grekler geldikten sonra da pek çok milletler geldi. Yalnız ne varki bu karışıp kaynaşma sırasında Grek dili ve kültürü hepsinden öne geçti. Selçuklular geldikten sonra ise Anadolu'nun çehresi daha başka bir şekil aldı. Bundan seksen yıl önce Anadolu Ortodokslarının Rumca okuma-yazma bilmediklerini yukarıda belirtmiştik Bir cümle ile ifade edecek olursak, Papa Eftim'e göre, Türk olabilmek için insanın kendini Türk hissetmesi yeter. Yalnız bu hissin, Papa Eftim'inki gibi samimi olması şarttır.

İşte bu ruh ve bu ideal ile Papa Eftim Fener Patrikhanesine karşı mücadeleye başladı. Bu yüzden Anadolu'da hariçten gelme haksız taarruzların müslümanlan olduğu kadar hırıstiyanları da müteessir ettiğini açıklayan bir beyanname yazdı. Bu beyannamede "...mezhebimizi şerre alet ederek, Türk olduğumuz halde Elenizm propagandasıyla iğfal edilerek güya aslen Yunanlı imiş ve aslına rücu edermiş gibi ekalliyet hukuku iddiasıyla mezhebi millete karıştırarak bir taraftan bizi Yunan âmaline alıstırmak desiselerini istimal ve diğer taraftan da umumî vekilimiz imişcesine hakkımızı istiyoruz der gibi vaziyetler alarak Avrupaya karşı hükümetimizden müştekî sıfat ve vaziyetiyle göstermeye kalkıştılar..." diyerek Fener'in tam aksi yönde bir istikamet aldı. Buna karşılık Patrikhane, Keskin metropolit vekili Papa Eftim'e tamim göndererek, Türkiye'nin Yunanistan'a verildiğini, Türkiye Hükümetinin verdiği vereceği emirlere itaat edilmemesini ve artık Ortodoks Rumların Türk uyruğunda kalmalarına lüzum kalmadığını bildiriyordu. Papa Eftim'in sözleri ve hareketleri nihayet şikâyet konusu oldu. Aralık 1918 de Patrikhane devrin sadrazamı Tevfik Paşa' ya bir takrir verip, Papa Eftim'in tevkif edilerek teslimini istedi ${ }^{19}$.

Papa Eftim Anadolu'da oturduğu müddetçe İstanbula tesirli olamayacağını anlayınca, Anadolu'da bağımsız bir Ortodoks Kilisesi

\footnotetext{
18 Aynı broşür.

19 Ergene, Teoman; ayn eser, s. 9.
} 
kurmaya karar verdi. Bunun için geniş ölçüde çalışmalara başladı. Sonunda Kayseri'de umumî bir kongre toplamayı başardı. Bu iş için T.B.M.M. Hükümeti Adliye Vekâletinden izin ald ${ }^{20}$. Yalnız bu kongre için ụ̧̈ ruhanî başkan bulunması gerekliydi. Anadolu'dakiler ise ya kaçmışlar ya da kaçmak üzereydiler. Yalnız Konya metropolidi Prokobiyos, Maçka metropolidi Kirillos, Antalya episkoposu Meletyos ve Gümüşhane episkoposu Yervasyos Anadolu'da idi. Papa Eftim çeşitli sebepler yüzünden bunları Kayseri'de toplamakta ve ikna etmekte epeyce güçlük çekti. Bunlardan Prokobiyos, Yervasyos ve Meletyos ${ }^{21}$. Kayseri'ye geldi. Ayrica bu kongreye Anadolu ve Trakya'da bulunan seksen ruhanî daire davet edildi. Bunlardan Fener Patrikhanesinin nüfuzu altında bulunan İstanbuldaki sekiz ruhanî daire katılmadı. Kongre arefesi çok gürültülü ve çekişmeli geçti. Bu ön çalışmalar sırasında şu tekliflerin kongreye sunulmasına karar verildi:

a-Kanun ve nizamlara aykırı olarak patrik seçilen Meletyos Metaksis patriklikten çlkarılacak ve Fener Patrikhanesi feshedilecek.

b-Kayseri'de bağımsız bir Türk Ortodoks Patrikhanesi kurulacak.

c-Kilise ve cemaatler tarafından noterliklerce tanzim edilmiş vekâletnamelerle Papa Eftim'e "Anadolu Ortodoks kilisesinin umumî vekilliği ve murahhaslığı" payesi verilecek.

21 Eylül 1922 de Kayseri'de, Konya metropolidi Prokobiyos'un başkanlğı altında kongre toplandr ${ }^{z_{2}}$. Papa Eftim'in etkili bir nutkuyla açılan kongrede daha önce düzenlenmiş bulunan mazbata okundu. 72 ruhanî daire başkanlarının da iştirakiyle, yapılan teklifler ve tutulan mazbata ittifakla kabul edildi, Mazbata esas olarak şunları ihtiva ediyordu $:^{23}$

"İşbu bin dokuzyüz yirmiiki senesi şehr-i eylülünün yirmibirinci çarşamba günü, zevali saat üç raddelerinde, biz zirde vaziü'l-imza umum Anadolu Türk Ortodoks cemaatleri murahhasları, Konya metropolidi şerafetlu (Prokobiyos) efendi hazretlerinin taht-1 riyasetlerin-

20 Ergene, Teoman; aynı eser, s. 27.

$21 \mathrm{Bu}$, Patrik Meletyos Metaksis değil, Antalya episkoposu Meletyos'dur.

22 Ergene, Teoman; aynı eser, s. 54: Atanın Yurdu, aylık dergi, s. 16, 1 Şubat 1959.

23 Ergene, Teoman; ayn eser, s. 24. Bu kongreye ait vesikalarm hepsi Türk Ortodoks Patrikhanesi Arşivinde mevcuttur. 
de şerafetlu episkopos ${ }^{24}$ (Meletyos) efendilerle umum Anadolu Türk Ortodoksları murahhas-1 umumisi faziletlu Papa Eftim efendi ve Kayseri'de mevcut ruhban sınıfı hazır oldukları halde bi'l-ictima, asırlarJanberi biz umum Anadolu Türk Ortodokslarmnn merci-i ruhanîmiz olan Fener Patrikhanesinin, taraf-ı ilahî zirhimayesinde tevdi edilmiş olduğumuz hükümet-i celile-i Osmaniye ile kat-1 münasebet ve kilisemizin kavanin-i mevzuasına külliyen muhalif olarak idare-i mülkiye ile idare-i ruhaniye arasında tevazini muktezi bulunan ahengi ihlal ve Fener Patrikhanesiyle hiç bir münasebeti olmayan ve teb'a-i ecnebiyyeden bulunan (Meletyos Metaksis)i, patriklik makamina ikad etmiş bu suretle hem hükümet-i metbuamıza karşı adem-i itaate ve hem de hükümet-i metbuamızla biz teb'a-i sadıka arasında suitefhimat hususuna sebebiyet vermiş olduklarından ve bi'n-netice milleıimizi pek müşkül ve vahim bir vaziyete ilka ettiklerinden müekkillerimiz bulunan Anadolu Türk Ortodoks cemaatleri mukaddema hükümet-i milliyemize müteaddid ariza ve telgrafnamelerle müracaat ederek bu suretle kilisemizin kanunları ve teamülü ahkâmı hilafına olarak Fener Patrikanesinde husule gelen ahvali red ve protesto ve fekk-i irtibat ettiklerini dahi bütün âleme kerraren ilân ve ilâm eylediklerinden ve bizleri usul-i mevzua dairesinde kilisemizin ahkâm-ı şerifesine tevfikan Patrikhanemizin teşkil hususunun mütevakkff bulunduğu umurun kâllisini ifaya mezun olmak üzere tevkif ettiklerinden İstanbul'da patriklik makamını gasbetmiş olan Meletyos Metaksis efendinin mezkûr makamın gasıbı bulunduğunu ve binaenaleyh hiç bir veçhile Türkiye Büyük Millet Meclisi Hükümetine tâbi umum Türk Ortodokslarının patriki bulunmadığını ilan etmekle beraber ve şimdilik patrik intihabı ise muzaffer Türk Ordularımızın ve gayr-i ruhanî murahhaslarımızın iştirakiyle ictima olunacak meclis-i umuminin davet-i ictima ve in'ikadına mütevakkıf bulunduğundan ve bunun temini dahi ahval-i hazıra ilcaatiyle kabil olamayacağından esamisi bâlada zikredilen episkopos efendilerle teşekkül eden cemaat, metrepolitler ile kilisemiz kongresi tarafından intihab olunan Çene oğlu Filip, Boyacı oğlu Kozma, Kostaki, Fehmi, Yorgi Orologos, Teofilos, Ayan oğlu Todor, Çömlekçi oğlu Mihalaki, Bullu oğlu İstimat Zihni efendilerden mürekkep daimî meclis-i muhtelite, birlikte patrikhane nizamnamesi ahkâmına tevfikan umur-ı ruhaniye ve mezhebiyemizi

24. Episkoposluk ve piskoposluk ayn makamdır. Piskopos, episkoposun yanlıs telaffuz edilmiş şeklidir. 
tedvir ve ileride patrik intihabatı istihzaratına tevessül etmek üzere, reis-i müşarünileyh Prokobiyos efendi hazretlerinin Türkiye Büyük Millet Meclisi Hükümetine tâbi umum Türk Ortodoksları patrik kaymakamı intihab ettiğimizi ve merci-i aidinden umur-1 resmisinin istihsali zımnında işbu mazbata-i intihabiyemiz üç nüsha olarak tanzim ve umum hazırun tarafindan hatt-1 destimizle imza edildikten sonra, biri Kayseri sancağı mutasarrıfiyyet-i aliyyesine, diğeri Türkiye Büyük Millet Meclisi Hükümetine tâbi umum Türk Ortodoks patrik kaymakamı rütbetlu Prokobiyos efendi hazretlerine ve üçüncüsü de umumî murahhasımız ve mümessilimiz Papa Eftim efendi hazretlerine takdim kılındı. 21 Eylül 1922.

İmzalar

Konya metropolidi : Prokobiyos

Antalya episkoposu : Meletyos

Gümüşhane episkoposu : Yervasyos

Türk Ortodoks Cemaat ve Kiliseleri Vekil-i Umumîsi ve Murahhası: Papa Eftim".

Böylece Prokobiyos patrik kaymakamı tayin edildi ve hepsi halktan olmak üzere oniki kişilik bir Sen Sinod Meclisi kuruldu. Kayseride bağımsız bir Türk Ortodoks Patrikhanesinin kurulması ve bunun beyannamelerle ilânı üzerine, Fener Patrikhanesinin faaliyetleri daha çok arttı. İstanbul ve Anadolu'da işlenen cinayetlere yenileri eklendi ${ }^{25}$.

Kayseri'de Türk Ortodoks Patrikhanesi kurulunca Fenerdekiler bu kuruluşun kendileri tarafından tasdik edilmediğini ve bağımsız bir kilise olamayacağını ileri sürdüler. Halbuki Fener Patrikhanesi kurulurken de Roma Katolik Kilisesi bu kuruluşu tanımamış ve afaroz etmiști. Buna rağmen Fener Patrikhanesi bağımsız bir kilise olarak yaşadı.

Bir müddet sonra Papa Eftim'in, yıkmak istediği patrikhaneyi, Fenerdekilerle anlaşarak Kayseri'de yeniden kurduğu söylentileri yayıldı. Papa Eftim bu dedikoduların önünü almak için Kayseri'den ayrilıp, Ankarada oturmak gereğini duydu. Fakat Papa Eftim'in Kayseri'den ayrılmasıyla, bu yeni kurulmuş patrikhanenin tekrar Fener'in nüfuzu altına girme tehlikesi başgösterdi. Ayrica bu sırada Lozan gö-

25 Anadolu Hediyesi; ayhk dergi, sayı 2-3-4-5-6-7. 
rüşmeleri de son şeklini buldu ve yapılan anlaşmaya göre Anadolu'daki Ortodoks'larla Yunanistan'daki Türk'ler mübadeleye tabi tutuldu. Ancak bu karardan İstanbul'daki Ortodoks'lar ve batı Trakya'daki Türk'ler muaf tutuldular. Şurasını da önemle belirtmek gerekir ki Anadolulu olmasına rağmen Papa Eftim ve Akrabalarına bu anlaşma uygulanmadı. Bu ise mübadelenin, o zamanın siyasî icaplarına uyularak mecburen yapıldığını gösterir. Diğer taraftan Büyük Millet Meslisi Murahhasları Lozan'da Fener Patrikhanesinin Türkiye'den çıkarılmasını istedi. Bu sırada Kayseri'deki Ortodoks Patrikhanesi ise çoktan kurulmuştu. Eğer mübadele, istenerek yapılmış olsaydı Fener'le birlikte Kayserideki Patrikhanenin çıkarılması da teklif edilirdi. Halbuki barış görüşmeleri sırasında Türk Heyeti Fener Patrikhanesinin Türkiye'den çıkarılması üzerinde ısrarla durduğu halde, Kayseri Patrikhanesi hakkında böyle bir teklif bile yapmadı. Fener Patrikhanesinin Türkiye'den çıarılması teklifine Ortodoks olsun veya olmasın bütün hıristiyan devletler şiddetle itiraz ettiler. Bir çoğu sözleriyle Türkiye'yi tehdit etti. Hatta görüşmelerin bir daha kesilmesi tehlikesi bile belirdi. Bunun üzerine İsmet Paşa müttefikler ve Yunan murahhas heyetlerinin, Patrikhanenin bundan sonra siyasî ve idarî işlerle uğraşmayacağı, yalnız dinî meseleler çevresinde kalacağı hakkında konferansta söyledikleri sözleri ve verdikleri açık teminatları senet olarak aldı. Bu şartlar içinde ve aldığı teminatlar dairesinde teklifinden vazgeçti ${ }^{26}$.

Anadolu'daki Ortodoks'larla, Yunanistan'daki Türk'lerin mübadelesinden sonra Papa Eftim İstanbul'a gitti. Çünkü Anadoluda Ortodoks kalmayınca Keskin'de oturmayı manasız buldu. Böylece hem Fener Patrikhanesiyle yakından mücadele edebilir, hem de Anadolu'dan gidip İstanbula yerleşmiş olan Ortodoks'ları, Patrikhanenin zararlı çalışmalarına karşı koruyabilirdi.

İstanbul'da Tokatlıyan Oteline yerleşen Eftim'i ilk iki gün birçok Ortodoks ve Ermeni ziyaret etti. Üçüncü gün Fener Patrikhanesi, Maçka metropolitinin başkanlığında bir heyet gönderdi. Patrikhanenin ziyaretini iade etmek için Papa Eftim ertesi gün Patrikhaneye gitti. Fakat Sen Sinod Meclisine Meletyos değil, Kayseri metropolidi Nikolaos başkanlı ediyordu. $\mathrm{Bu}$ ve bundan sonraki ziyaretlerinde, mütareke sıralarında yapılan patriklik seçiminin usülsüz ol-

26 Prof. M. Cemil; Lozan, c. 2, s. 295. 
duğunu, müthiş ve müfrit bir Türk düşmanı olan ve aynı zamanda yabancı uyruklu bulunan Meletyos'un patriklikten ve Sen Sinod üyeliğinden çıkarılmasını istedi. Sen Sinod Meclisi bir taraftan Papa Eftime karşı oyalama taktiği güdüyor, bir taraftan da rumca gazetelerde Eftim'le müzakerelerinin kesildiğini ilan ediyorlardı. Bunun üzerine Papa Eftim Ankara'ya dönmeye karar verdi. Fakat dönmeden önce Türk gazetecileriyle bir basın toplantısı yaparak, patrikhane ile aralarında geçen konuşmayı tafsilatıyla anlattı. Artık İstanbul'da işi kalmadığından Ankara'ya döneceğini bildirdi. Bu arada Fener Patrikhanesinin tutumunu tasvip etmeyen İstanbul Ortodoks'larn ile aslen Anadolulu olan Ortodokslar olayı böylece öğrendi ve aralarında bir heyet kurarak Tokatlyyan Oteline gönderdi. Heyet Papa Eftim'den, İstanbul'dan ayrılmamasını ve kendilerine yardımeı olmasını istedi. Bunun üzerine Papa Eftim Ankara'ya dönmekten vazgeçti. İki gün sonra toplanan Sen Sinod Meclisi daha önce sunulan Papa Eftim'in tekliflerini görüşecekti. Bu yüzden Eftim ve kendini Ankara'ya dönmekten alıkoyan halk o gün Sen Sinod Meclisinin kararın beklemeye başladılar. Bir müddet sonra meclisin Papa Eftim'den başkaca izahat istemediği kararı gelince, halkın da arzusuyla hep birlikte Sen Sinod Meclisinin toplandığı odaya gidildi. Eftim Sinod üyelerine, evvelce yazılı olarak bildirdiği tekliflerini görüßsmelerini ve kesin kararı yarım saat içinde, bildirmelerini ihtar etti. Yarım saat geçmeden Patrik Meletyos'un çıkarıldığı ve diğer isteklerin ise peyderpey görüşüleceği bildirildi. Bunun yeni bir oyalama oyunu olduğunu anlayan Eftim, kilise ve cemaat heyetlerinin kararı olarak, Sen Sinod'un feshedildiğini ve derhal salonu terketmeleri haberini gönderdi. Arkasından Patrikhanenin bir başka odasında yeni bir Sinod Meclisi kurdu. Başkanlığı ise Erdek metropolidi Kalinikos üzerine aldı. Ilk iş olarak Meletyos'un azledildiği tasdik edildi ve Papa Eftim Patrikhane mümessilliğine geniş yetkilerle tayin edildi, (4 Teşrinievvel 339) 17 Ekim $1923^{27}$.

Bu günlerde batı Trakyadaki Türk'lere, Yunan'lılar daha fazla baskı yapmaya başladılar. Bu yüzden Türk halkı galeyana geldi. İstanbul'daki Ortodokslara misilleme yapılması istendi. Bunun üzerine Papa Eftim Ankara'ya gidip devrin başbakanı ve İçişleri bakan Vekili olan İsmet Paşa'yı ziyaret etti. Böyle bir olayın önü alındı. Ama Patrikhanenin bu olayı tel'in etmesi istendi. Papa Eftim bunun için Istan-

27 I numaralı vesika. 
bul'a telgraf çekti. Fakat telgraf aksi tesir yarattı. Papa Eftim'in de yokluğundan yararlanan Fener Patrikhanesi yine eski şekline döndü.

$\mathrm{Bu}$ arada boş bulunan patriklik makamına Yunanistan'ın entrikaları ile, yine bir Türk düșmanı olan Kadıköy metropolidi Grigoryos'un seçilme ihtimali belirdi. Bu haberi duyan Papa Eftim, hemen ailesini de alarak İstanbul'a döndü. Ancak kendisi Sen Sinod Meclisini görmeye gittiği zaman seçimin yapıldığı ve Grigoryos'un patrik olduğu bildirildi. Bunun üzerine Papa Eftim Patrikhane vekilliğinden istifa etti. $^{28}$ İstifa Patrikhanedekileri üzecek yerde sevindirdi. Bu duruma daha çok üzülen Papa Eftim, Patrikhaneye, Ortodoks Kilise ve Cemaatleri Umumî Vekili sıfatıyla bir kere daha el koyarak Patrik ve Sen Sinod'u azletti. Fakat bu da birincisi gibi uzun ömürlü olmadı. Mücadelesine Fener Patrikhanesi dışında devam etmeye karar vererek oradan ayrild.

Bu olaylar sırasında Galata Ortodoks Cemaati arasında anlaşmazlık çıktı. Patrikhane olay karşısında ne yapacağını şaşırdı. Çünkü Galata Ortodokslarının seçtiği merkez heyeti başkanı olan Damyanos Damyanidis Patrikhaneye baş kaldırmıştı. Ayrıca Galata merkez heyeti ile özel heyetleri arasında da ihtilaf vardı. Damyanos'a verilen ceza, sivil olduğu için afarozdan öteye gitmiyordu. Meseleyi halletmek üzere Papa Eftim'in yardımı istendi. Gerçekten Damyanidis ile bir görüşme yaptıktan sonra meseleyi halletti. Fakat Patrikhane bu defa Damyanidis'i Papa Eftim aleyhine kullanmaya başladı. Mesele yeniden karıştı. Sonunda cemaat da konu ile bizzat ilgilenmeye başladı. Anlaşmazlık aşağı yukarı bir yıl devam etti. Merkez ve mütevelli heyetler, kiliselerinin idaresini Papa Eftim'e vermeye ve Fener Patrikhanesinden ayrilmaya karar verdiler. 7 Temmuz 340/1924 de Papa Eftim'e müracaat ettiler ve kendisinden 9 Temmuzda müsbet cevap aldılar. Böylece Papa Eftim İstanbuldaki bağımsız Türk Ortodoks Patrikhanesi'nin temelini attı. Galatada bulunan Panaiya, Huristos, Aya Nikola ve Aya Yani Kiliselerinin başpapazlığını üzerine aldı. ${ }^{29}$ Bununla aynı zamanda Kayseri'deki bağımsız Türk Ortodoks Patrikhanesi İstanbul'a, Panaiya Kilisesine nakledilmiş oluyordu. Daha önce 6 Haziran 1924 tarihinde Panaiya Kilisesinde yapılan kongrede şu kararlar alınmıştı:

28 Ergene, Teoman; ayn eser, s. 91.

29 II numarah vesika. 
1 - Fener Patrikhanesiyle kati olarak dine ve dünyaya ait bütün alakaların kesilmesi.

2 - Kayseri'de evvelce kurulmuş olan Türk Ortodoks Merkez Kilisesinin İstanbul'a nakledilmesi ve bu Kilisenin başkanlığına Papa Eftim'in getirilmesi.

3 - Ortodoks Kilisesinin müstakil olması ve bu istiklalinin Hükümet tarafindan tasdikine ait gerekli muamelelere hemen başlanmasi.

4-Panaiya Kilisesinin, Türk Ortodoksluğunun merkezi olarak tanınmasi.

6 Haziranda yapllan bu kongreden sonra 9 Temmuzda Papa Eftim başpapazlık görevini kabul etmişti. 14. Temmuz 1924 de ise topladığı yeni bir kongrede kilise idaresine bakmakla görevli bir heyet teşkiliyle Patrikhaneye ait bir nizamname tanzim edildi. 14 Temmuz kongresi ile 6 Haziran kongresi kararlarn hemen hemen aynidır. Yalnuz son toplantıda eski kararlara ilave edilen 5. Madde önemlidir. "Madde 5-Bir kilise nizamnamesinin kaleme alınarak, kongrede kabul edilen nizamnamenin Hükümetimizce kabul ve tasdikine kadar, yine ruhanî reis Eftim efendinin reisliği altında olmak üzere, avukat İstimat Zihni, Damyanos Damyanidis, Koço Papadopulos, Zamba Zambaoğlu, Dimosteni Papadopulo, Yani Bülbüloğlu efendilerden mürekkep daimî bir cismanî heyet teşkilini, Sokrat Karahisarlığlu, Kiryako Gölcoğlu, Anastas Manoloğlu, Nikola Vasilyadis, Kiryako Pamukoğlu efendilerin de bu heyetin ihtiyat azaları olmak üzere intihabın ve bu heyetin, reis-i ruhanî Eftim efendinin riyaseti altındaki daimî ruhanî heyet ile birleşmek suretiyle teşekkül edecek ruhanî ve cismanî muhtelit meclis tarafindan Kiliseye ait bütün umur ve hususun idare edilmesini kabul ve ol veçhile karar verdiğimize dair işbu mazbatamızı iki nüsha olarak tanzim ve imza ile reis-i ruhanîmiz Eftim efendiye ifa ettik". ${ }^{30}$

Kabul edilen Kilise nizamnamesi, bir ek maddeyle birlikte 20 maddeden ibaretti. 4. maddede, Türk Ortodoks cemaatinin sadece dinî yönden ayrıldığı, bunun dışında Müslüman Türk vatandaşlar ile hiçbir ayrılıkları olmadığı belirtilmiş, azınlık sıfat ve hukuku kaldırılmıştır. 6. maddede, seçilen patriklerin hükümetin tasvibine sunulması

30 Ergene, Teoman; aynı eser, s. 189. 
kabul edilmiştir. 7. maddede, başpapaz, papaz ve diyagosların azli yetkisi yalnız Türkiye Cumhuriyeti Hükümetine verilmiştir. 10. maddede, ruhanî memurların dinî kıyafetleriyle umumî yerlerde gezmeleri yasak edilmiştir. Bunun dışındaki maddeler Patrikhanenin dinî ve idarî işleriyle ilgilidir.

1925 yllında Patrik Grigoryos öldü. Yerine seçilecek patrik hususunda Sinod üyeleri arasında mücadele başladı. Çünkü Yunanistan' daki siyasî bölünmeye paralel olarak Fener papazları arasında da "kıralcı" ve "venizelist" diye iki grup meydana gelmişti. Bunlardan kıral taraftarı olan Konstantinos patrik seçildi. Fakat Yunanistan'da iktidar mevkiinde bulunan Venizelos taraftarları İstanbul'da bulunan mübadele komisyonu nezdinde, gerçekten büyük bir maharetle yaptıkları müracaatlar sonunda Patrik Konstantinos'u mübadeleye tabi tutmaya muvaffak oldular. Aynca mübadele işinin Türk Hükümeti tarafından yapıldığını ileri sürerek umumi efkârı yanlış yola sevkettiler.

Patrik seçimlerinden sonra sabık Kayseri metropoliti Amorsiyos, Erdek metropolidi Kirillos ve Adalar metropolidi Ağatangelos'un yaptığı bir ayinle, Papa Eftim'e Fener Patrikhanesi tarafindan verilen afaroz cezası kaldırıldı ve kendisi piskoposluğa yükseltildi, 18 Mart $1926{ }^{31}$ Böylece Papa Eftim bağımsız bir patrikhanenin Baş Episkopos'u oldu. ${ }^{32}$

Papa Eftim'in bu başarılarına karşı Fener Patrikhanesi yeni mücadele vasitaları aradı ve Papa Eftim'i bir çok uydurma suçlarla mahkemeye verdi. Papa Eftim her seferinde beraat etti. Bütün davalar kendi lehine sonuçlandı. Daha mücadelesinin başından itibaren Fener Patrikhanesinin içyüzünü yansıtan beyannameler yayınlamış ve halka Fener Kilisesinin emel ve gidişatını açıkça göstermişti. ${ }^{33}$

Bir ara Türk Ortodoks Patrikhanesinde yeni reformlara girişen Papa Eftim, dua ve ilahîleri, yani ibadeti türkçe yaptırmaya başladı. Bu da Fener Patrikhanesinin yeni bir hücumuna yol açtı. İbadetin

31 III numaralı vesika.

32 Episkoposlarm evlenebileceği, Pavlus'un Timoteos’a gönderdiği birinci mektubun üçüncü babında yazlıdır. Kitabu'l-ahdü'l-cedid, s. 256-257, Paris, 1827.

$33 \mathrm{Bu}$ beyannamelerin metni Teoman Ergene'nin adı geçen eserinde neşredilmiştir, s. $144-185$. 
rumcadan başka bir dille yapılamayacağını ileri sürdü. Oysaki Arap lar Mısır'ı fethettikten bir müddet sonra kiliselerdeki ayinler arapça yapılmaya başlanmıştı. ${ }^{34}$ Bununla da sonuç elde edemeyen Fener Kilisesi açıtan açığa Papa Eftim ve ailesine küfür etmeye, Türk Ortodokslarına saldırmaya başladılar. Papa Eftim ve taraftarlarının bulunduğu Galata bölgesindeki Ortodoksların işlerini yapmadılar. Bu arada Papa Eftim bir firsatın bulup Balıkl Hasatahanesini ele geçirdi. Hükümetin izniyle yeni bir heyet seçildi. Yeni idare heyetinin başkanı, 1922 de Kayseri'de kurulan Türk Ordodoks Patrikhanesînin Sen Sinod üyeliğinde bulunmuş olan avukat İstimat Zihni efendi idi. Önceleri Papa Eftim'in en yakın arkadaşı olan İstimat Zihni İstanbula gelince, hele yine Papa Eftim'in tavsiyeleriyle milletvekili olunca Fener'le anlaştı. Arkasından hastahanede Papa Eftim taraftarı olanları birer birer çıkardı. Hatta baştabip Yusuf Petraki beyi de işten uzaklaştırarak hastahanenin idaresini tamamen kendi eline aldı.

Fener'dekiler, Papa Eftim'in ölümünü sabırsızlıkla bekliyordu. Çünkü o ölürse Patrikhanenin çöküp dağılacağını umuyorlardı. Bu sebeple Papa Eftim Türk Ortodoks cemaatini büyük bir toplantıya davet etti. Toplantıda Fener Kilisesinin aralarına soktuğu bozguncu ve casuslarnn yapacaklarn herhangi bir kötü harekete meydan vermemek için kendilerine sadık papazlar tayin etmek gerektiğini bildirdi. Fakat, cemaatin sözbirliği ile lüzumunu kabul ettikleri bu papazların, o günler için bulunması imkânsızlığını ileri sürerek, ahlâk ve seciyelerine, dinî bilgi, inanç ve itikadlarına emin olduğu akrabaları arasın* dan papazlar yetiştirmek niyetinde bulunduğunu söyledi Amcasının oğlu ile yeğenini ve o sıralarda yüksek öğrenimini bitirmek üzere bulunan büyük oğlunu bu papazlıklara aday gösterdi. Hazır bulunan herkesin tasvibiyle teklif kabul edildi. Bunun üzerine Papa Eftim, amcasının oğlu Sokrat'a "Ermiş", yeğeni Nikola'ya "Doran" adlarını vererek papazhı̆a ve oğlu Yorgi'ye "Turgut" adın vererek diyagos" luğa tayin ve üçünü de takdis etti. Bununla Patrikhanenin geleceği teminat altına alınmış oluyordu ${ }^{35}$.

II. Dünya Savaşı sıralarında Papa Eftim, Fener Patrikhanesine karşı mücadelesini nisbeten yavaşlattı. Çünkü Rusya savaştan galip

34 Becker, Carl H.; Beitraege zur Geschichte Aegyptens Unter dem Islam, Zweites Heft., s. 131, Strassburg, 1903.

35 Ergene, Teoman; aynı eser, s. 233. 
çıkmıştı ve Türkiye'ye karşı olan tutumu belli değildi. Bu sırada Ortodokslar arasındaki bir karışıklık Rusya için bir bahane olabilirdi. Hatta Yunanistan suni olarak olay yaratmak istediyse de başaramad.

$\mathrm{Bu}$ durgunluk devresi Kıbrıs olaylarının başlamasıyla sona erdi. Kıbrıs'ta başpiskopos Makarios'un Türklere karşı işlediği cinayetler Fener Patriki Athenagoras tarafindan yerilmedi. Türk gençliği ve basın, haklı olarak bu konuda Fener Patrikhanesini suçladılar. Onlara ortak olmakla itham ettiler. Bunun üzerine Papa Eftim 15 Haziran 1958 de umumî bir kongre tertip etti. Burada bir çok kararlarla birlikte "Kıbrıstaki Türk irkdaşlarımıza yapılan haksız ve yolsuz taarruz ve tecavüzün din ve Ortodoks mezhebimize ve insanlığa aykırı görüldüğünden; başta, dinî siyasete alet edip, bütün kötülüğün müsebbibi olan katil Makarios'u ve ona uyan ve Hıristiyan adını taşıyan her türlü teşekkülü tel'in etmeğe ve medenî âleme karşı bu namertçe hareketin protesto edilmesine" karar verildi. Ayrica bu kararla birlikte Papa Eftim'in bazı beyanatı broşür halinde aynı yıl neşredildi. Yine Patrikhanenin resmî gazetesi ve Rum basını Türklük ve Papa Eftim aleyhine yazılar neşretmeye başladılar. Papa Eftim 14 Mart 1968 tarihinde öldüğü güne kadar bunlarla mücadeleye devam etti. Öldükten sonra, büyük oğlu ve 24 ylllk diyagos'u Dr. Turgut Erenerol, "II. Papa Eftim" adıyla yerine geçti ${ }^{36}$.

$36 \mathrm{Bu}$ yazıyı hazırlarken Türk Ortodoks Patrikhanesi Arşivinden yararlanmamı sağlayan ve bana bu konuda sonsuz yardımları dokunan Patrik II. Papa Eftim'e (Dr. Turgut Erenerol) teşekkür etmeyi bir borç bilirim. 


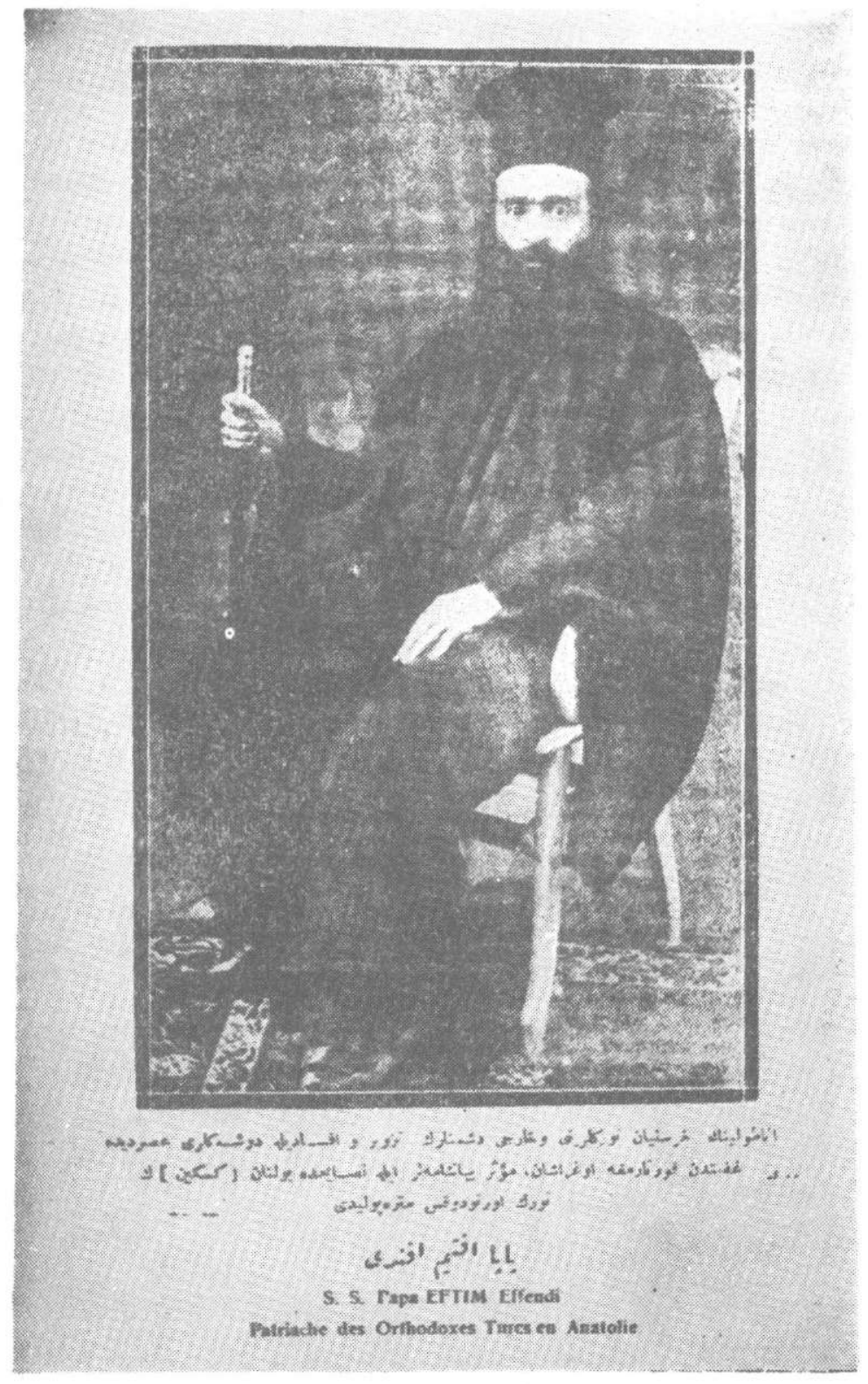

Kurtuluş Savaşı yıllarında Papa Eftim 


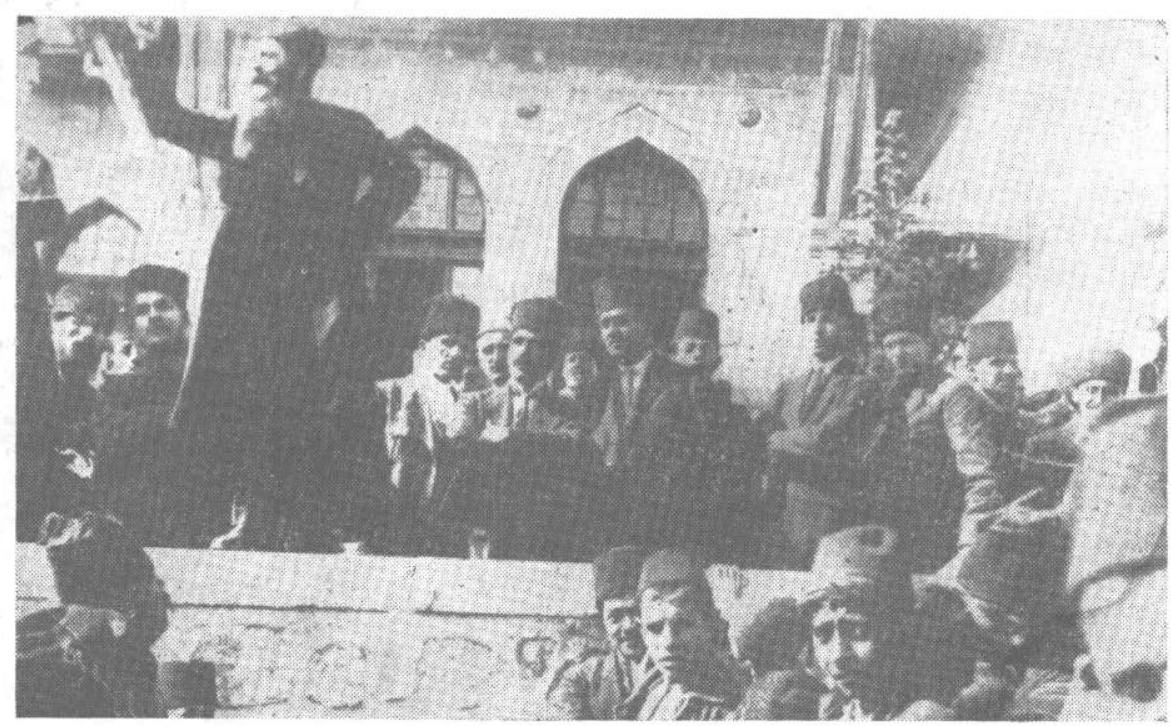

Papa Eftim 1922 yılında, B.M.M. nin bahçe duvarı üzerinde konuşurken

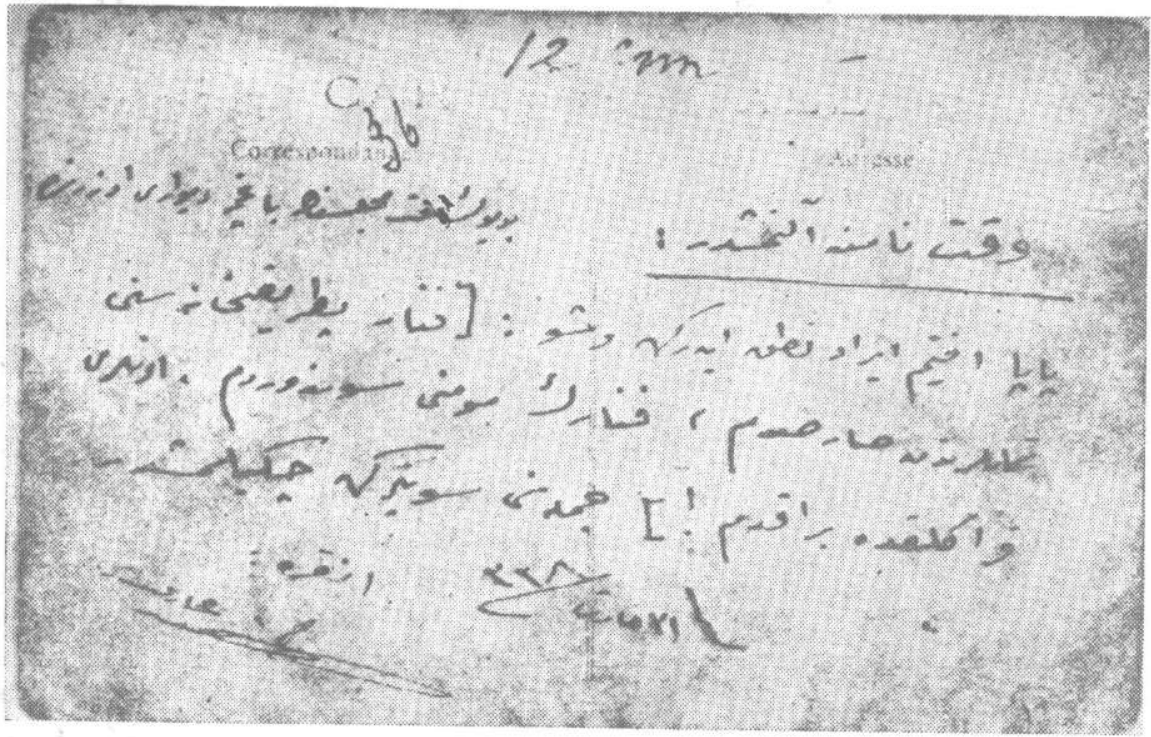

Ústteki fotoğrafin arkasındaki not 


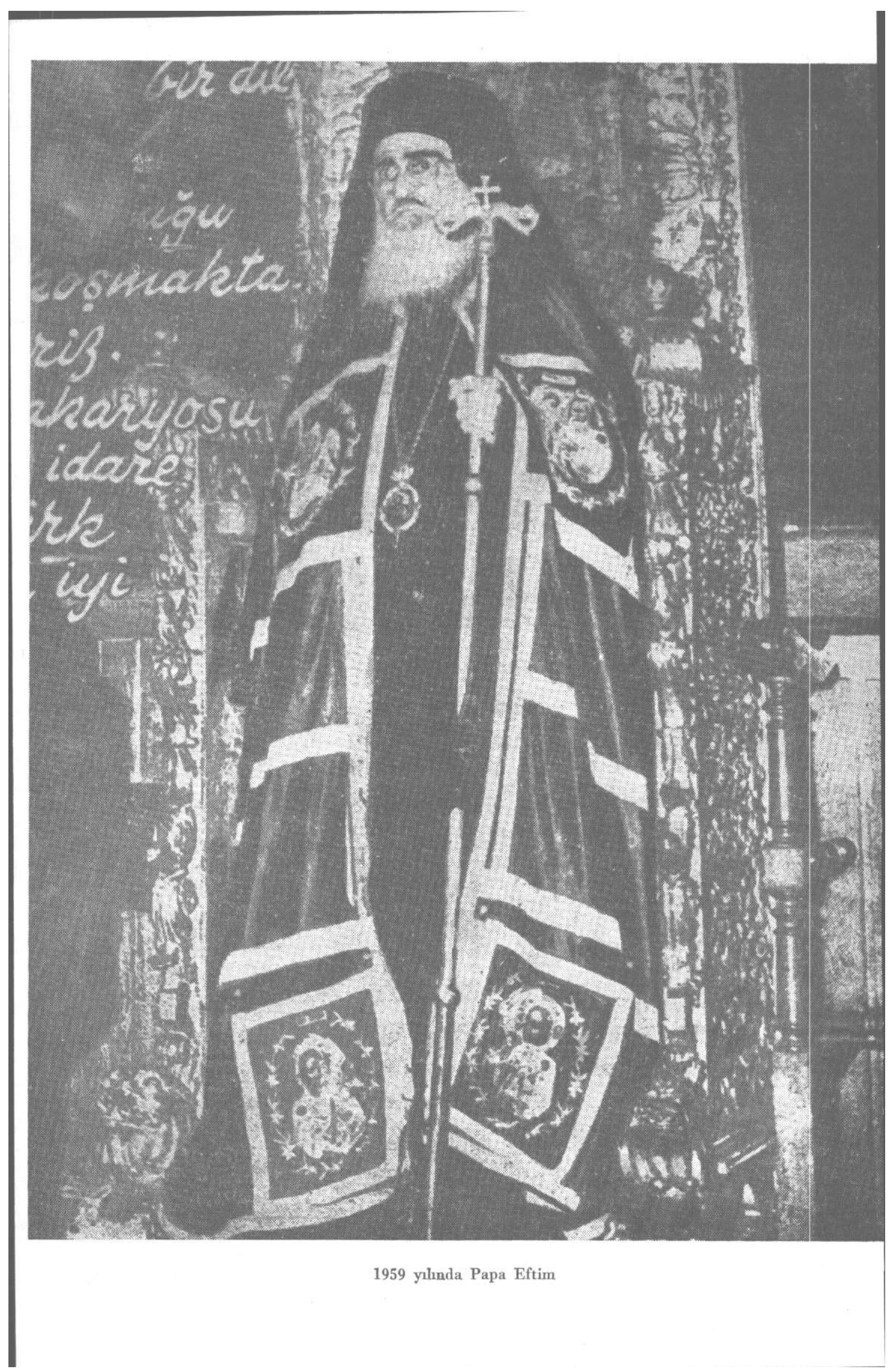




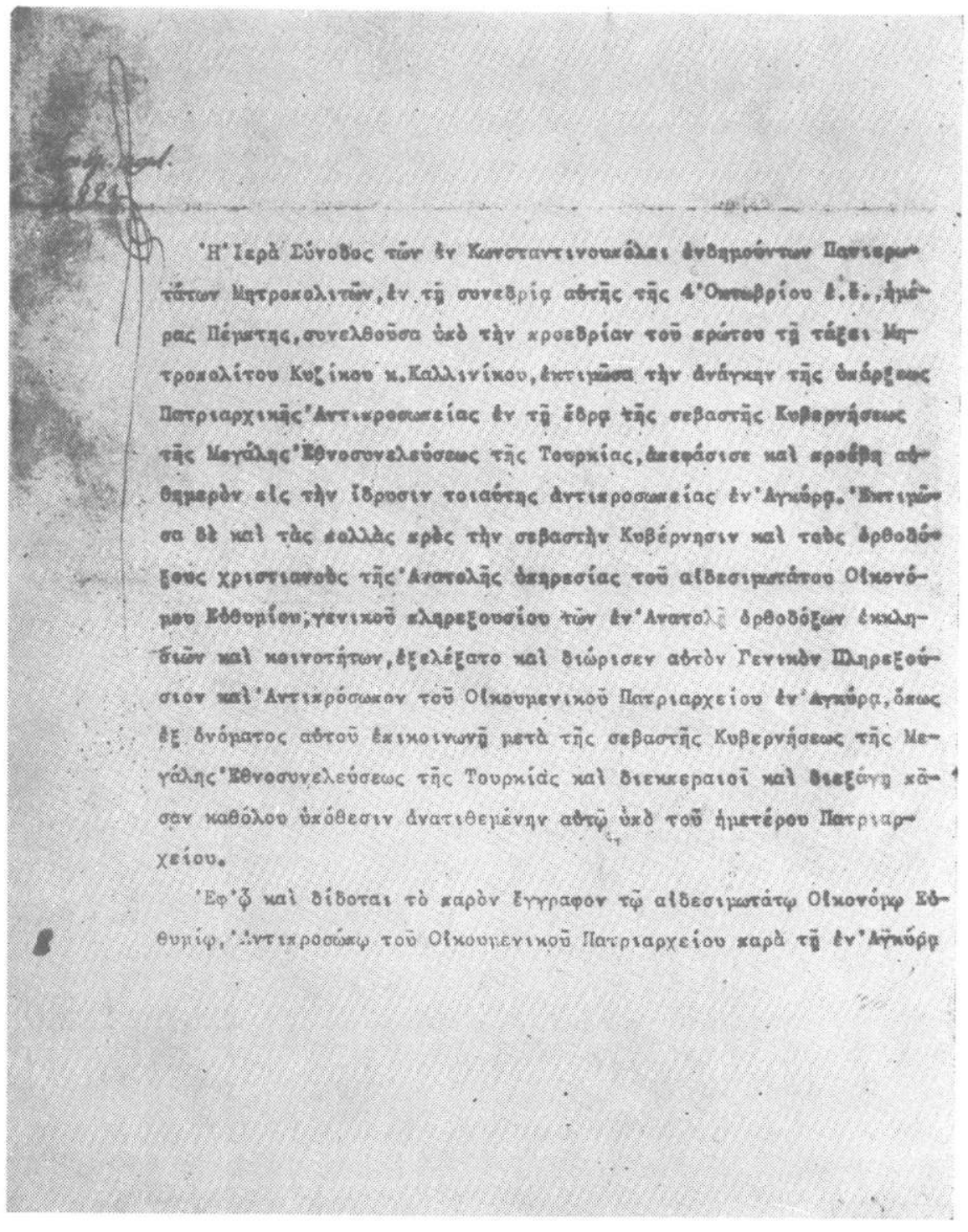

I. vesikanın ash (1. sayfa) 


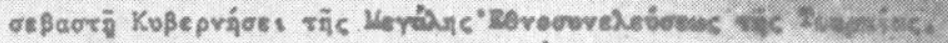

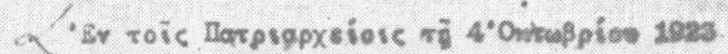

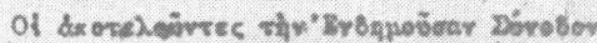

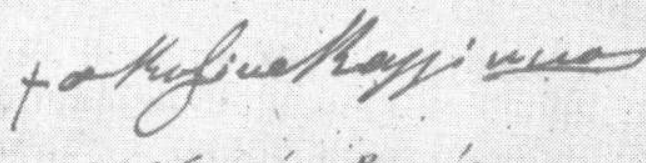

+UNuxás Barideas.

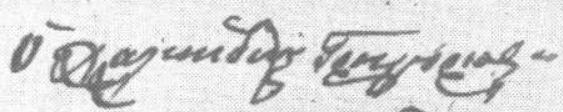

iTparion Kumenion

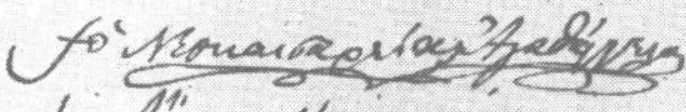

ti fivi.. 1/. acerat.

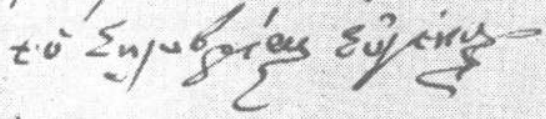

to-Podrozun kipys

- ixvíarvafear

I. vesikanin asl (2. sayfa) 


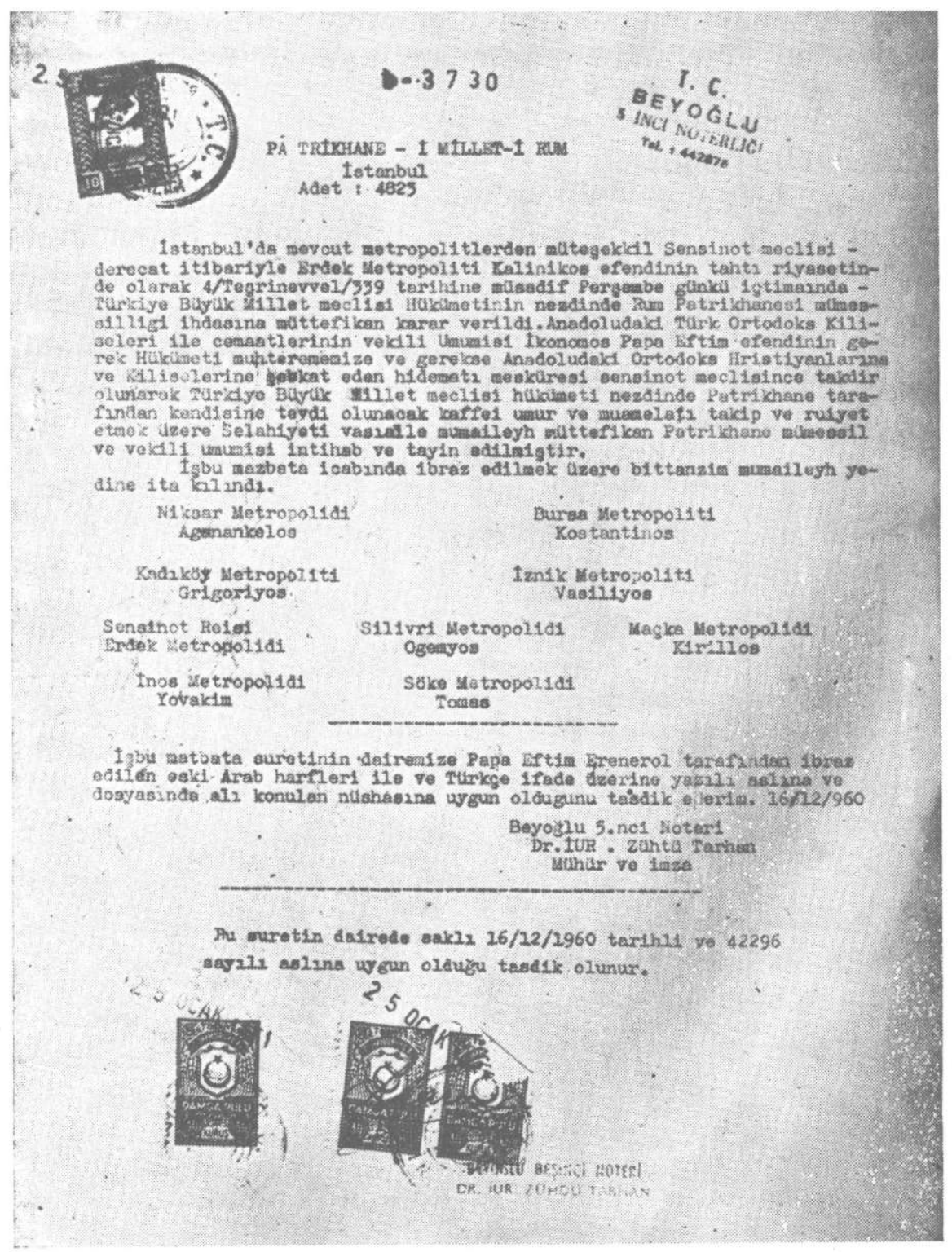

I. vesikanın tercümesi

(Tercüme Arap harfleriyle yazılı olan nüshasından yapılmıştır). 


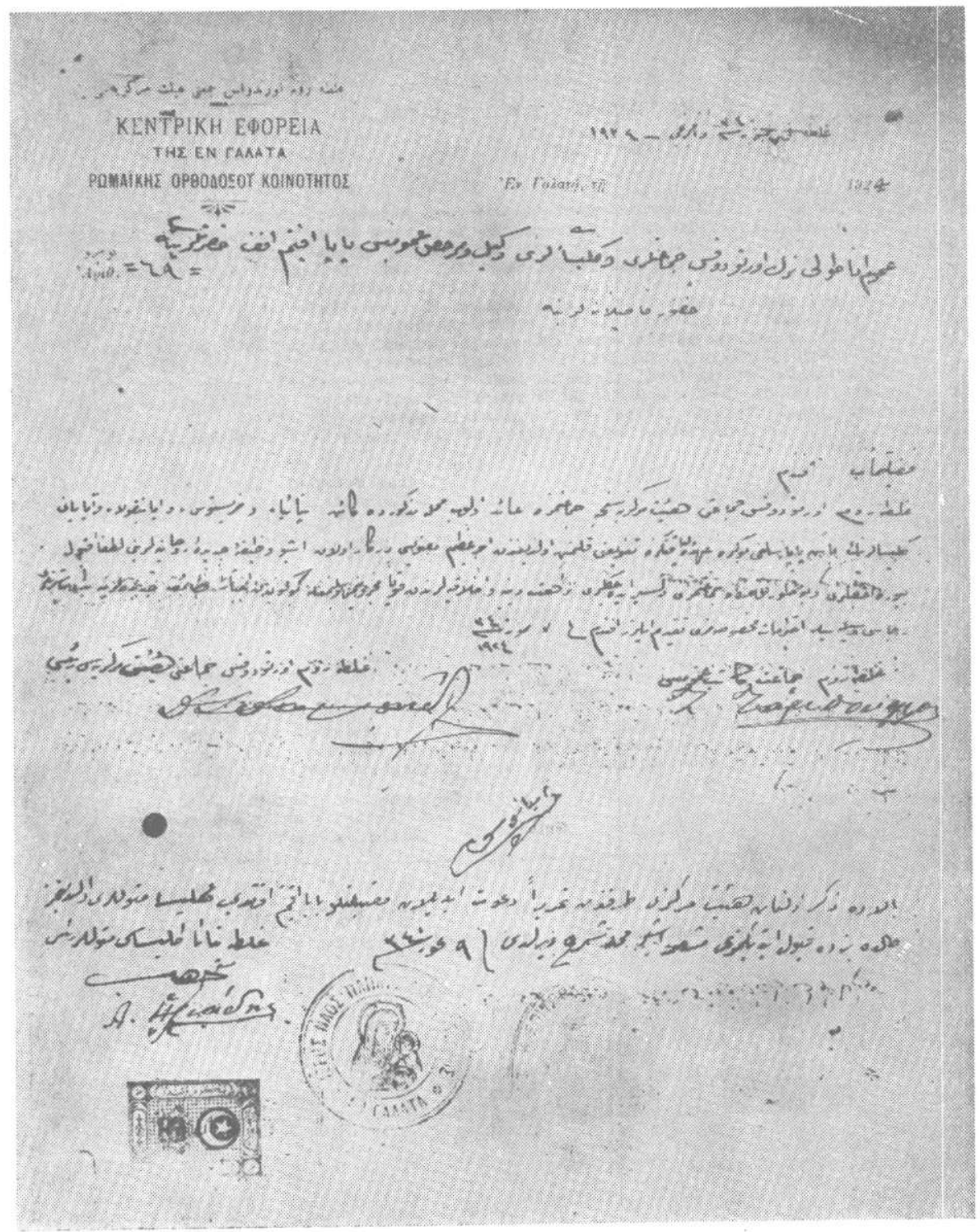

II. vesika 


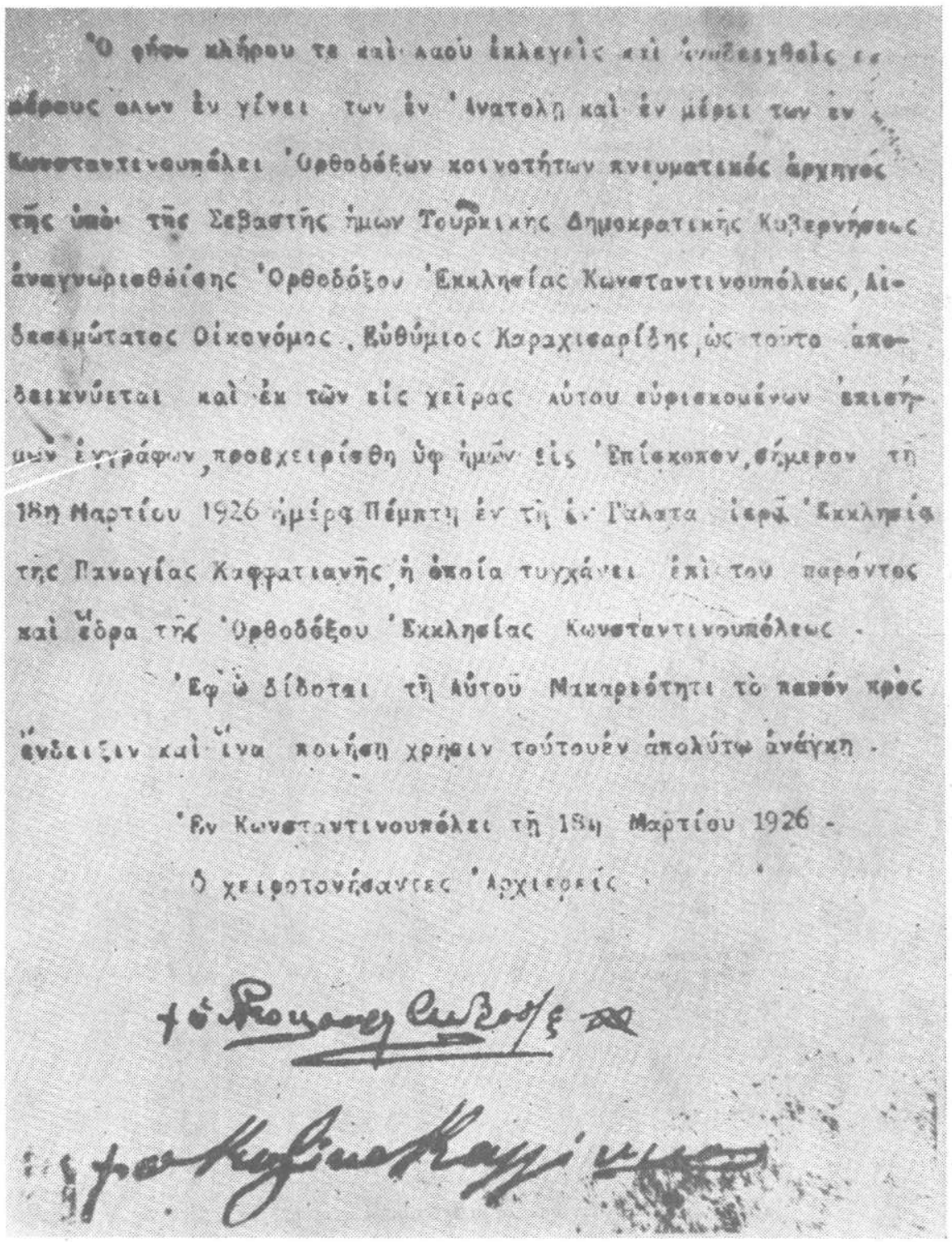

III. vesikanın ash 


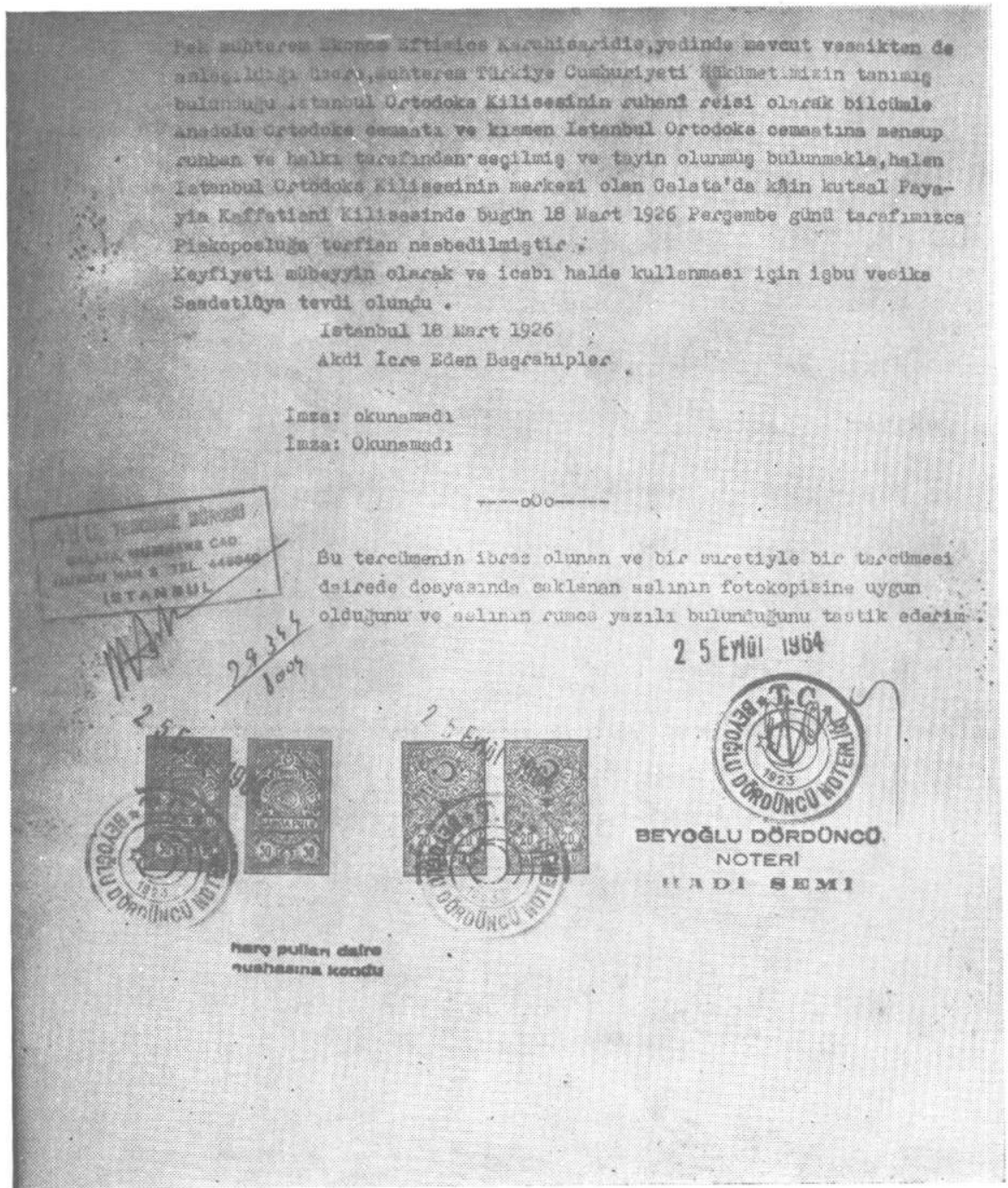

III. vesikanın tereümesi 